\title{
Prevalence of tumors in dogs from the municipality of Toluca, México, from 2002 to 2008
}

\author{
Prevalencia de tumores en perros del municipio de Toluca en el periodo 2002-2008
}

\author{
R Fajardo a*, A Alpízara , LS Pérez ${ }^{\mathrm{a}}$, JS Martínezª ${ }^{\mathrm{a}}$ E Córdovab \\ aÁrea de Patología Quirúrgica, Departamento de Patología Animal, Centro de Investigación y Estudios Avanzados en Salud Animal \\ (CIESA), Facultad de Medicina Veterinaria y Zootecnia, Universidad Autónoma del Estado de México, Toluca, México. \\ 'Instituto Nacional de Medicina Genómica, , México, D.F.
}

\begin{abstract}
RESUMEN
Los estudios epidemiológicos del comportamiento tumoral pueden generar datos importantes sobre la aparición espontánea de neoplasias en animales. En Toluca se carecen de datos epidemiológicos sobre oncología veterinaria. Este estudio de prevalencia de tumores está basado en la población total de perros con dueño del municipio de Toluca y es el primero que se realiza en México. Se recibieron en el Laboratorio del CIESA, durante el periodo 2002/2008 un total de 172 tumores y la prevalencia estimada fue de 1.23/1000 perros con dueño. La prevalencia en hembras fue de 1.37 y en machos de 1.08. La frecuencia de tumores por grupos de edad fue: $59.3 \%$ en perros de 7-15 años, $33.7 \%$ en perros de 2 a menores de 7 años y el $7 \%$ en perros menores de 2 años. La raza que presentó frecuentemente tumoraciones fue el Labrador (18.4\%). Los tumores más prevalentes fueron los tumores de piel con una prevalencia de 0.65 , seguido de los tumores de glándula mamaria (0.24). Estos resultados muestran que la edad podría estar relacionada en la aparición de tumores malignos y que el factor UV podría relacionarse con la presencia de algunos tipos de tumores cutáneos. Este estudio contribuye al entendimiento epidemiológico de los tumores en perros del municipio de Toluca, con el propósito de establecer el primer Registro de Tumores de perros en México.
\end{abstract}

Palabras clave: perros, prevalencia de tumores, Toluca, México.

\section{SUMMARY}

The purpose of this study was to estimate the prevalence of tumors in biopsies of owned dogs sent to the pathology laboratory from the municipality of Toluca. Tissue samples $(\mathrm{n}=172)$ were received at CIESA laboratory from 2002 to 2008. The estimated prevalence was $1.23 / 1000$ dogs, with values of 1.37 for bitches 1.08 for males. The frequency of tumors per age group was: 59.3\% in dogs of 7-15 years old, $33.7 \%$ in dogs of 2-6 years old and $7 \%$ in dogs younger than 2 years old. Skin tumors were the most prevalent $(0.65)$, followed by mammary gland tumors $(0.24)$. These results suggested that age could be associated to the presence of malignant tumors, and that UV radiation could be associated to the appearance of certain types of skin tumors. This study contributes to the understanding of the epidemiology of tumors in dogs from Toluca, in order to establish the first registry of dog tumors in Mexico.

Key words: dogs, tumors prevalence, Toluca municipality, México.

\section{INTRODUCTION}

Tumors develop due to an uncontrolled continuous proliferation of cells that became unable to respond appropriately to the signals that rule normal cell behavior, growth and division. Cells divide uncontrollably, invading healthy tissues and organs, some of them metastasizing to other areas of the body (Kumar et al 2005). Neoplasms are considered an inherited genetic disorder in only 5\% of the cases. In the remaining 95\% they appear spontaneously, causing primary DNA damage during the life of the individual (Avadhani 1998), associated with some environmental factors (chemicals, radiation, oncogenic viruses) that directly or indirectly produce chan-

Accepted: 02.05.2013.

* Carretera Toluca-Atlacomulco Km. 15.5. CP. 50200, Toluca, México; raul_fajard@hotmail.com ges in the cellular genome (Lyman 1992). Cancer is the most common disease of companion animals, reaching $15-30 \%$ in dogs and $26 \%$ in cats, and it leads to death or euthanasia (Brønden et al 2009).

Epidemiological studies of tumors may generate important data about the spontaneous emergence of neoplasms in animals, provide information about risk factors, help evaluate different treatments, and provide information about trends in the distribution of cancer (Kumar et al 2005). In addition, these studies are important and can have a considerable impact due to the fact that animals can act as sentinels of environmental factors that could be involved in human diseases. With regard to human cancer, the dog has been proposed as the best study model, as they are exposed to most environmental factors that allegedly cause tumors and cancer in humans, being the species we share spaces with and, sometimes, food habits; moreover, the histology and biology of cancer are similar in both species (Bukowski and Wartenberg 1997, Kelsey 
et al 1998, Vail and MacEwen 2000). In the U.S.A and Europe, the incidence of tumors in pets has been estimated using different methodologies and variable reference populations which include patients admitted to hospitals or registered by a veterinary pet insurance company (Reif 2007). In Toluca, there is a lack of epidemiological data on animal oncology. For this reason, it is essential to start gathering information in order to establish a statistical record on the behaviour of this disease in the dog population and to determine whether there are any risk factors in the municipality of Toluca that are associated to this disease.

The aim of this study was to estimate the prevalence of tumors in owned dogs in the municipality of Toluca from biopsies sent to the pathology laboratory.

\section{MATERIAL AND METHODS}

A descriptive and a retrospective epidemiological study was performed. In order to make inferences about frequencies a chi-square test $(\chi 2)$ and $P$ value of less than 0.05 were used as criteria for statistical significance. Out of all the biopsies sent to the CIESA laboratory between 2002 to 2008 only those with a diagnosis of neoplasm were selected. Anamnesis data (sex, age, breed and clinical-pathological features of the tumor) were captured in a database using Word and Excel (database from the Surgical Pathology area in CIESA, 2002/2008). Prevalence was estimated from all the tumor cases, according to sex, location and the histogenesis and biological behaviour of the tumors. These data were extrapolated to the population of owned dogs in the municipality of Toluca. The total population of owned dogs in the study period was estimated at 139,900 dogs, based on official records from the Instituto de Salud del Estado de México (Pérez and L'Gamiz 1995). To estimate tumor prevalence by gender, we assumed that estimated $49 \%$ of the dogs in the studied population were males and $51 \%$ females (Pérez and L'Gamiz 1995). Regarding age and animal breed, it was only possible to estimate the frequencies for all tumor cases. The diagnosis of biopsies was done by histopathology; samples were processed by conventional methods and special stains were used according to the type of tumor (Masson's Trichrome, Giemsa, PAS and Fontana). All neoplasms were classified according to the International Histological Classification of WHO and of the Armed Forces Institute of Pathology, with cooperation from the American Registry of Pathology (AFIP/OMS 2004).

\section{RESULTS AND DISCUSION}

A total of 172 samples were diagnosed as tumors, with an estimated a prevalence of 1.23/1000 dogs among the total population of 139,000 owned dogs. With regard to gender, there was a prevalence of 1.37 in females and of 1.08 in males (figure 1).
In this study, the estimated incidence of tumors $(1.23 / 1000)$ in owned dogs from the municipality of Toluca is relatively low compared with a reported incidence of 3.71/1000 in an Italian county (Merlo et al 2008). It is difficult to compare the obtained results with other studies because most scientific reports of dog tumors in veterinary medicine estimate frequencies or incidences using partial populations of dogs, either from clinics and hospitals or from insurance companies, with most pets suffering from some kind of pathology. In addition, there are no prevalence reports that consider the total population of dogs (sick and healthy) in a city or town. The difference in tumor incidence between sexes may be influenced by the high incidence of mammary tumors, as it is one of the most common tumors in females (Benjamin et al 1999, Rutteman et al 2007).

In terms of age, the highest frequency of tumors was detected in dogs between 7 - 15 years old $(59.3 \%)$, while in dogs from 2 to 7 years old the frequency was $33.7 \%$, and $7 \%$ in dogs younger than 2 years old (figure 2). Malignant tumors occurred most frequently $(65.3 \%, 49 / 75)$ in older animals; $(\mathrm{P}=0.0318)$. Older dogs showed the highest frequency of cancer in both females and males. This may be explained by the fact that their tissues had been exposed for longer periods to undetermined risk factors, and also due to the decreasing physiological ca-

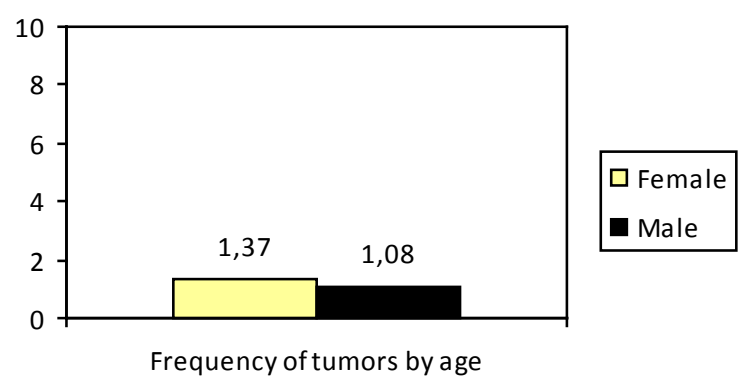

Figure 1. Prevalence of tumors by sex/1000 dogs. Prevalencia de tumores por sexo/1000 perros.

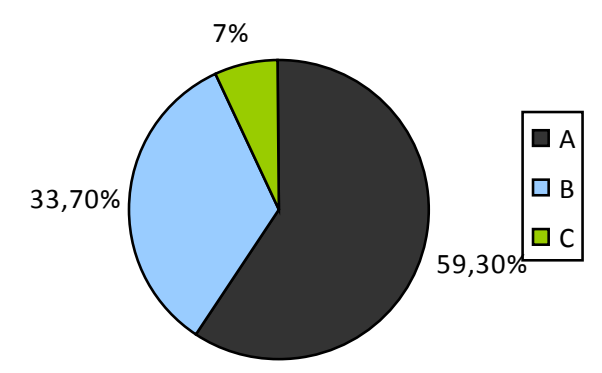

A) $<2$ years, B) 2-7 years old, C) $>7-15$ years old.

Figure 2. Frequency of tumors by age. Frecuencia de tumores por edad. 
pacity for cellular repair as the animals grow older; therefore, they may have been accumulating cellular damage, which predisposes to the development of neoplasia (Ferbeyre and Salinas 2005, Hartwell and Kastan 1994). Furthermore, the senescence of the immune system results in a deficient immune response against carcinogenic agents and altered cells, allowing the development of tumor diseases (Burns and Goodwin 1997, Ferbeyre and Salinas 2005, Fietta 2008). The fact that the largest proportion of tumors $(90.1 \%)$ was found in adult dogs (older than 2 years old) suggests that the exposure to risk factors (dietary deficiencies, chronic infections or free radicals) can initiate the development of tumors, since the accumulation of at least four to seven gene mutations is required for cancer cells to initiate a tumor process (Renan 1993). Age could be an important risk factor, mainly for the development of malignant tumors; however, further studies should be conducted in order to prove this statement.

Pure breed dogs were found to have a higher frequency of tumors $(91.9 \%)$ when compared with mixed breed dogs $(8.1 \%)$ (table 1$)$. When comparing dog breeds, tumors were more frequently found in Labrador (18.4\%), followed by Schnauzer and Cocker (8.2\%), German Shepherd and French Poodle (7.6\%) (table 2). In this study, Labrador was the breed with more tumors (18.4\%); these results agree with other studies which reported that this breed is at greater risk of developing tumors (Juárez and Aburto 2004). Our results could possibly be influenced

Table 1. Frequency of tumors by breed in owned dogs in the municipality of Toluca (2002-2008).

Frecuencia de tumores en perros por Raza/Mestizos del municipio de Toluca (2002-2008).

\begin{tabular}{lcc}
\hline & No. of cases & $\%$ \\
\hline Purebred & 158 & 91.9 \\
Mixed breed & 14 & 8.1 \\
\hline
\end{tabular}

Table 2. Frequency of tumors in dogs by breed. Frecuencia de tumores en perros por raza.

\begin{tabular}{lcc}
\hline Breed & No. of cases & $\%$ \\
\hline Labrador Retriever & 29 & 18.4 \\
Schnauzer & 13 & 8.2 \\
Cocker Spaniel & 13 & 8.2 \\
German Shepherd & 12 & 7.6 \\
French Poodle & 12 & 7.6 \\
Rottweiler & 8 & 5.1 \\
Bull Terrier & 7 & 4.4 \\
No registration & 7 & 4.4 \\
Others & 57 & 36.1 \\
\hline
\end{tabular}

by the fact that Labrador is the most popular breed in the municipality of Toluca. Our findings differ from those of Moulton, who reported that the Boxer breed developed more tumors by type and numbers (Misdorp 1990). In our study, the Boxer breed accounts for only $3 \%$ of all tumors.

According to the location in the body, skin tumors were predominant, with a prevalence of 0.65 , followed by mammary gland tumors $(0.24)$. Other body regions in which tumors were found with a lower prevalence were: reproductive, digestive, hematopoietic, musculoskeletal, respiratory, urinary and the endocrine systems (table 3). Regarding to location in the body of tumors related to gender, skin tumors ranked first in females with a prevalence of 0.59 ; mammary gland tumors were in second place, with a frequency of 0.45 . Skin tumors also predominated in males, with a frequency of 0.45 , followed by reproductive system $(0.13)$ and gastrointestinal $(0.08)$ tumors. The differences in tumor prevalence were significant $(\mathrm{P}=0.00000427)$. Skin tumors were the most prevalent, mainly appearing in older animals, in agreement with other studies (Dobson et al 2002, Kelsey et al 1998, Pires et al 2003, Richards et al 2001). This is possibly due to the skin being the tissue most exposed to various environmental factors that can trigger tumor development (Vail and Withrow 2007). Furthermore, it is the most visible organ, easy to explore and access for obtaining tissue samples. Mammary gland tumors were the second most prevalent, but the appearance of this kind of tumors is influenced by sex, as it was clearly observed they were less prevalent in males, in agreement with results from other studies (Benjamin et al 1999, Pires et al 2003). The high occurrence of mammary gland tumors in bitches was probably due to hormonal factors, since the risk of tumor development in dogs spayed before the first estrus is low $(0.05 \%)$; is spayed after the first estrus the risk increases to $8 \%$, and rises to $26 \%$ if they are spayed after the second estrus (Ginn et al 2007, Rutteman et al 2007).

In this study, skin and mammary gland tumors were the most prevalent. There were no differences among the repor-

Table 3. Prevalence of tumors found by affected tissue $/ 1000 \mathrm{dogs}$. Prevalencia de tumores por ubicación tisular/1000 perros.

\begin{tabular}{lcc}
\hline Location in tissues & No. of cases & Prevalence \\
\hline Skin & 91 & 0.65 \\
Mammary Gland & 33 & 0.24 \\
Genital System & 17 & 0.12 \\
Digestive & 13 & 0.10 \\
Skeletal-Muscle & 7 & 0.05 \\
Hematopoietic & 6 & 0.04 \\
Respiratory & 3 & 0.02 \\
Urinary & 1 & 0.007 \\
Endocrine & 1 & 0.007 \\
\hline
\end{tabular}


ted tumor frequencies in large cities from other countries with similar environmental pollution (Dobson et al 2002, Kelsey et al 1998, Pires et al 2003, Richards et al 2001).

Of all the different kinds of tumors found, carcinoma showed the highest prevalence with 0.17 , followed by fibroma (0.09) and adenoma (0.08). As for skin tumors, the most prevalent were fibroma (0.08), histiocytoma (0.06) and pilomatricoma (0.05) (table 4). With regard to histopathological features of tumors, $56.4 \%$ were diagnosed as benign and $43.6 \%$ as malignant, with a prevalence of $0.70 / 1000$ dogs and $0.54 / 1000$ dogs respectively (figure 3 ).

Even though the most prevalent skin tumor was fibroma (0.08), the group of tumors linked to UV exposure, such as squamous cell carcinoma, hemangiosarcoma and hemangioma (Nikula et al 1992) had a higher prevalence (0.09). This could be associated with high levels of UV light (8-10) reported in Toluca. Therefore, as mentioned

Table 4. Prevalence of skin tumors by kind/1000 dogs. Prevalencia de tumores de piel/1000 perros.

\begin{tabular}{lcc}
\hline Tumor & No. of cases & Prevalence \\
\hline Fibroma & 12 & 0.08 \\
Histiocytoma & 9 & 0.06 \\
Pilomatricoma & 7 & 0.05 \\
Squamous cell carcinoma & 6 & 0.04 \\
Infundibular keratinizing & 5 & 0.03 \\
acanthoma & & \\
Fibrosarcoma & 5 & 0.03 \\
Melanoma & 5 & 0.03 \\
Hemangioma cutaneous & 4 & 0.028 \\
Mast cell tumor & 4 & 0.028 \\
Trichoblastoma & 4 & 0.028 \\
Hamartoma collagenous & 3 & 0.021 \\
Hemangiosarcoma cutaneous & 3 & 0.021 \\
Lipoma & 3 & 0.021 \\
Infundibular cyst & 3 & 0.021 \\
Trichoepithelioma & 3 & 0.021 \\
Sebaceous adenoma & 2 & 0.014 \\
Basal cell carcinoma & 2 & 0.014 \\
Lymphoma & 2 & 0.014 \\
Squamous papilloma & 2 & 0.014 \\
Apocrine cells adenoma & 1 & 0.007 \\
Undifferenciated carcinoma & 1 & 0.007 \\
Hemangiopericytoma & 1 & 0.007 \\
Liposarcoma & 1 & 0.007 \\
Myxoma & 1 & 0.007 \\
Transmissible Venereal Tumor & 1 & 0.007 \\
Fibropapilloma & 1 & 0.007 \\
\hline & &
\end{tabular}

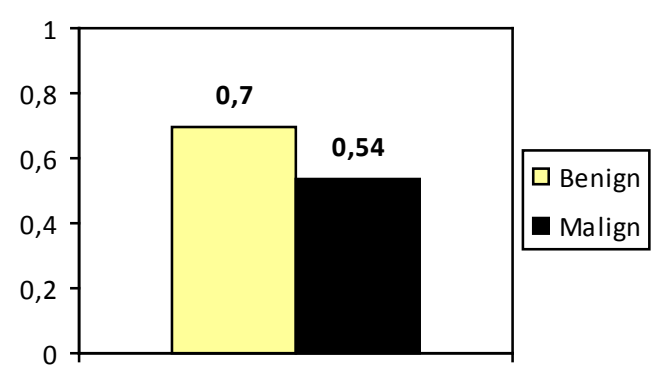

Figure 3. Prevalence of tumors by histopathological features: benign/malign/1000 dogs.

Prevalencia de tumores por características histopatológicas: benigno/maligno/1000 perros.

by other authors, exposure to UV light should be considered a likely risk factor related to the high skin tumor prevalence found in Toluca city.

As CIESA is the only histopathology laboratory in this municipality, it is considered a regional monitor of domestic animal diseases. However, since only a small proportion of all dog tumor cases in Toluca city reach our laboratory, due to either economic reasons or lack of interest of the owners, this study is likely to have underestimated the prevalence of tumors, and further studies should be conducted in order to get a more accurate assessment of the prevalence of tumors in dogs from this municipality.

This is the first reported effort to establish a dog tumor registry in Mexico. It is important to expand this kind of studies in order to learn more about tumor behaviour in this species. In addition, a continuous effort should be conducted in order to asses regional risk factors and compare them with risk factors for tumors in humans, as the dog could be a sentinel of external risk factors in our environment and could provide valuable information to the authorities involved in the design of public health programs. To the best of our knowledge, this is the first report on the prevalence of dog tumors among the population of owned dogs in the municipality of Toluca, contributing to the understanding of the epidemiology and the risk factors associated with some dog tumors.

\section{ACKNOWLEDGEMENTS}

The authors thank the Universidad Autónoma del Estado de México for partial financial and institutional support, and Dr. Dionicio Cordova from INIFAP for his statistical contributions.

\section{REFERENCES}

Armed Forces Institute of Pathology in cooperation with the American Registry of Pathology and The World Health Organization collaborating Center for Comparative Oncology. 2004. International Histological Classification of Tumors of Domestic Animals. $2^{\text {nd }}$ Series. Washington, DC., USA. 
Avadhani NG. 1998. Cancer in Dogs. Proceedings of the 28th Annual Canine Symposium at VHUP. Pennsylvania, USA.

Benjamin SA, AC Lee, WJ Saunders. 1999. Classification and behavior of canine mammary epithelial neoplasms based on life-span observations in beagles. Vet Pathol 36, 423436.

Brønden LB, S Lindstrand, SS Nielsen, N Toft, AT Kristensen. 2009. Validation of data collected in the Danish Veterinary Cancer Registry. Vet Comp Onc 7, 207-211.

Bukowski J, D Wartenberg. 1997. An alternative approach for investigating the carcinogenicity of indoor air pollution: Pets as sentinels of environmental cancer risk. Environ Health Perspect 105, 1312-1319.

Burns EA, JS Goodwin. 1997. Immunodeficiency of aging. Drugs Aging 11, 374-397.

Cormier SA, S Lomnicki, W Backes, B Dellinger. 2006. Origin and health impacts of emissions of toxic by-products and fine particles from combustion and thermal treatment of hazardous wastes and materials. Environ Health Perspect $114,810-817$.

Dobson JM, S Samuel, H Milstein, K Rogers, JLN Wood. 2002. Canine neoplasia in the UK: estimates of incidence rates from a population of insured dogs. J Small Anim Pract 43, 240-246.

Ferbeyre B, G Salinas. 2005. Bases genéticas y moleculares del cáncer. $1^{\text {a }}$ parte. Gamo 4, 32-39.

Fietta P. 2008. The immunosenescence. Riv Biol 101, 247-64.

Ginn EP, JEKL Mansell, PM Rakich. 2007. Neoplastic and reactive diseases of the skin and mammary glands in skin and appendages. In: Maxie GM (ed). Jubb, Kennedy and Palmer Pathology of Domestic Animals. $5^{\text {th }}$ ed. Vol 1. Saunders Elsevier, Philadelphia, USA, Pp 746-781.

Hartwell L, M Kastan. 1994. Cell Cycle Control and Cancer. Science 266, 1821-1828.

Juárez M, E Aburto. 2004. Revisión de 558 casos de neoplasias en perros durante el periodo 2000-2004. Departamento de Patología, FMVZ-UNAM. Memorias del XIII Congreso Nacional de Patología. Nayarit, México.

Kelsey JL, AS Moore, LT Glickman. 1998. Epidemiologic studies of risk factors for cancer in pet dogs. Epidemiol Rev 20, 204-217.

Kumar V, AK Abbas, N Fausto. 2005. Neoplasia. In: Kumar V, Abbas AK, Fausto N (eds). Robbins and Cotran's Pathology Basis of Disease. $7^{\text {th }}$ ed. Elsevier Saunders, Philadelphia, USA, Pp 269-342.
Lana S, G Rutteman, SJ Withrow. 2007. Tumors of the mammary gland. In: Withrow SJ, MacEwen EG (eds). Small animal clinical oncology. $4^{\text {th }}$ ed. Saunders Company, Philadelphia, USA, Pp 619-633.

Lyman GH. 1992. Risks factors for cancer. Prim Care 19, 465-479. Merlo DF, L Rossi, C Pellegrino, M Ceppi, U Cardellino. 2008. Cancer incidence in pet dogs: findings of the Animal Tumor Registry of Genoa, Italy. J Vet Intern Med 22, 976-984.

Misdorp W. 1990. General considerations in Tumors. In: Moulton $\mathrm{J}$ (ed). Tumors in domestic animals. $3^{\text {rd }}$ ed. University of California Press, Los Angeles California, USA, Pp 1-21.

Nikula KJ, SA Benjamin, GM Angleton. 1992. Ultraviolet radiation, solar dermatosis and cutaneous neoplasia in Beagle dogs. Radiat Res 129, 11-18.

Pérez SL, L'Gamiz MA. 1995. Proyecto de fortalecimiento para el programa de control y vigilancia epidemiológica de la rabia. Tesis de Maestría en Salud Pública. Jurisdicción Sanitaria $\mathrm{N}^{\circ} 1$ Toluca. I.S.E.M. Instituto Nacional de Salud Pública, Escuela de Salud Pública de México.

Pires MA, TF Seixas, I Pires. 2003. Neoplasias em canídeos. Um studio descriptivo de 6 anos. RPCV 98, 111-118.

Reif JS. 2007. The epidemiology and incidence of cancer. In: Withrow SJ, MacEwen EG (eds). Small animal clinical oncology. $4^{\text {th }}$ ed. Saunders Company, Philadelphia, USA, Pp 68-76.

Renan MJ. 1993. How many mutations are required for tumorigenesis: Implications for human cancer data. Mol Car$\operatorname{cinog} 7,139-146$.

Richards HG, PE McNeil, H Thompson, SWJ Reid. 2001. An epidemiological analysis of a canine-biopsies database compiled by a diagnostic histopathology service. Prev Vet Med 51, 125-136.

Rothman KJ, S Greenland. 1998. Types of epidemiology studies. In: Rothman KJ, Greenland S (eds). Modern Epidemiology. $2^{\text {nd }}$ ed. Lippincott Williams\&Wilkins, Philadelphia, USA, Pp 71-78.

Vail D M, EG MacEwen. 2000. Spontaneously occurring tumors of companion animals as models for human cancer. Cancer Invest 18, 781-92.

Vail MD, SJ Withrow. 2007. Tumors of the skin and subcutaneous tissues. In: Withrow SJ, MacEwen EG (eds). Small animal clinical oncology. $4^{\text {th }}$ ed. Saunders Company. Philadelphia, USA, Pp 375-401.

Woodward M. 1999. Epidemiology study design and data analysis. Chapman \& Hall/CRC, Florida, USA, Pp 1-28. 
